\title{
FAKTOR-FAKTOR YANG MEMENGARUHI INTENSITAS NYERI PASIEN PASCA OPERASI FRAKTUR EKSTREMITAS BAWAH DI BRSU TABANAN
}

\section{Factors Influence Pain Intensity Patient Post Operation Lower Limb Fracture In BRSU Tabanan}

\author{
I Putu Artha Wijaya ${ }^{1}$, Kadek Evi Yantini ${ }^{2}$, I Made Dwie Pradnya Susila ${ }^{3}$ \\ ${ }^{1,3}$ Dosen Departemen Keperawatan Medikal Bedah STIKes Bina Usada Bali \\ ${ }^{2}$ Mahasiswa Pogram Studi S1 Keperawatan STIKes Bina Usada Bali \\ Korespondensi: artha_wijaya001@yahoo.com
}

\begin{abstract}
ABSTRAK
Nyeri yang dirasakan pasca operasi disebabkan karena terjadinya torehan, tarikan, manipulasi jaringan dan organ. Hasil penelitian ini memberikan deskripsi karakteristik dari responden dan menjelaskan faktor-faktor yang mempengaruhi intensitas nyeri pasien pasca operasi fraktur ekstremitas bawah. Rancangan penelitian ini adalah deskriptif analitik dengan pendekatan cross sectional pada 30 responden pasca operasi fraktur ekstremitas bawah. Pengambilan sampel dilakukan dengan teknik insidental sampling. Hasil penelitian menunjukkan bahwa faktor faktor yang berhubungan secara signifikan terhadap intensitas nyeri pasien pasca operasi fraktur ekstremitas bawah adalah jenis kelamin $(p=0,001)$, tingkat pendidikan $(p=0,001)$, mekanisme koping $(p=0,001)$ dan dukungan keluarga $(p=0,001)$ dengan nilai $\alpha=0,05$ sedangkan faktor usia $(p=0,330)$ dan pengalaman tindakan operasi yang menyebabkan nyeri $(p=0,770)$ yang artinya tidak ada hubungan faktor usia dan pengalaman tindakan operasi yang menyebabkan nyeri terhadap intensitas nyeri pasien pasca operasi fraktur ekstremitas bawah $(p>0,05)$. Hasil penelitian ini bermanfaat bagi praktisi keperawatan sebagai acuan asuhan keperawatan dalam melakukan manajemen nyeri pasca operasi fraktur ekstremitas bawah untuk mempertimbangkan faktor jenis kelamin, tingkat pendidikan, mekanisme koping dan dukungan keluarga.
\end{abstract}

Kata Kunci: Faktor nyeri, operasi fraktur ekstremitas bawah

\begin{abstract}
Fracture post-surgery patients often complain pain, pain which is felt after surgery caused by nick, pull, and also manipulation of tissues and organs. The results of this study aimed at providing description of respondents' characteristics and explaining the factors affecting patients' pain intensity of post-surgery lower limb fracture.The design of this study was descriptive analytic with cross sectional approach on 30 respondents of post-surgery lower limb fracture. Sampling was done by incidental sampling technique. The results of this study indicated that the factors significantly related to the patients' pain intensity of post-surgery lower limb fracture were gender $(p=0.001)$, education level $(p=0.001)$, coping mechanism $(p$ $=0.001)$ and family support $=0.001)$ with $\alpha=0.05$ while age factor $(p=0,330)$ and experience of surgery action causing pain $(p=0,770)$ meant that there was no relation of age factor and experience of operation action causing patients' pain intensity of post-surgery lower limb fracture $(p>0.05)$. The results of this study are benefit for nursing practitioners as a reference of nursing care in performing post-surgery lower limb fracture pain management in order to consider gender factors, educational level, coping mechanisms and family support. It is suggested that further research with a larger number of samples and other factors that can affect pain should be developed.
\end{abstract}

Keywords: Pain factor, fracture operation lower limbs 
I Putu Artha Wijaya: Faktor-faktor Yang Memengaruhi Intensitas Nyeri Pasca Operasi Fraktur Ekstremitas Bawah

\section{Pendahuluan}

Fraktur merupakan suatu keadaan dimana terjadinya disintegritas tulang atau terputusnya kontinuitas jaringan tulang yang ditentukan sesuai jenis dan luasnya. Fraktur terjadi jika tulang dikenai stres yang lebih besar dari yang dapat diabsorpsi, apabila tekanan eksternal yang datang lebih besar dari yang dapat diserap tulang, maka terjadilah trauma pada tulang yang mengakibatkan rusaknya atau terputusnya kontinuitas tulang(Rendy \& Margareth, 2012).

Penyebab terjadinya fraktur adalah insiden kecelakaan, peristiwa trauma dan patologi seperti infeksi, dan osteoporosis (Septiani, 2015). World Health Organization (WHO) mencatat pada tahun 2011 terdapat 1,3 juta orang menderita fraktur akibat kecelakaan lalu lintas. Depkes RI (2011), fraktur pada ekstremitas bawah akibat kecelakaan memiliki prevalensi yang paling tinggi yaitu sekitar 46,2\%. Data registrasi Dinas Kesehatan Provinsi Bali (2011), didapatkan data fraktur sebanyak 3065 kasus $(8,9 \%)$ dari seluruh penyakit yang dirawat di Rumah Sakit di Bali (Damayanti, 2014).

Berdasarkan studi pendahuluan di BRSU Tabanan Bali pada tanggal 5 Juni 2017, di ruang Unit Data Pelayanan BRSU Tabanan Bali pada tahun 2015 tercatat kasus fraktur sebanyak 762 kasus. Pada tahun 2016 tercatat kasus fraktur meningkat yaitu sebanyak 810 kasus. Pada tahun 2017, Januari sampai September tercatat 629 kasus dengan prevalensi cukup tinggi yaitu kasus fraktur ekstremitas bawah 286 orang atau sekitar $46 \%$ pasien fraktur ekstremitas bawah dilakukan tindakan operasi (Unit Data Pelayanan BRSU Tabanan Bali, 2017). Operasi atau pembedahan merupakan tindakan pengobatan yang menggunakan cara invasif yaitu dengan membuka atau memperlihatkan bagian tubuh yang akan ditangani. Tindakan pembedahan dapat dipastikan mengakibatkan kerusakan jaringan tubuh yang menimbulkan rasa nyeri pada pasien pasca operasi, nyeri yang dirasakan ini disebabkan karena terjadinya torehan, tarikan, manipulasi organ, iskhemia jaringan akibat gangguan suplai darah kesalah satu bagian seperti spasmus otot atau odema dan dapat juga terjadi akibat stimulasi ujung saraf oleh bahan kimia yang dilepaskan pada saat operasi (Nurhafisah, 2012).

Pasien pasca operasi fraktur seringkali mengeluh rasa nyeri. Nyeri merupakan suatu sensasi subjektif, nyeri menurut IASP (International Association for the Study of Pain) adalah pengalaman sensori dan emosional yang tidak menyenangkan akibat dari kerusakan jaringan yang aktual dan potensional (Hidayati, 2013). Stimulus penghasil nyeri mengirimkan impuls melalui serabut saraf perifer. Serabut nyeri memasuki medula spinalis dengan menjalani salah satu dari beberapa rute saraf. Terdapat pesan nyeri berinteraksi dengan sel-sel saraf inhibitor mencegah stimulasi nyeri, sehingga tidak mencapai otak atau ditransmisikan tanpa hambatan ke korteks serebral. Sekali stimulus nyeri mencapai korteks serebral, maka otak akan menginterpretasikan kualitas nyeri dan memproses informasi tentang pengalaman dan pengetahuan yang lalu serta kebudayaan dalam mempersepsikan nyeri (Pasaribu 2011).

Hasil observasi dan wawancara yang dilakukan oleh peneliti dengan perawat dan pasien pada tanggal 5 Juni 2017 di ruang Bougenvile BRSU Tabanan Bali, didapatkan data bahwa masalah utama yang terjadi pada pasien pasca operasi fraktur ekstremitas bawah adalah nyeri. Pengkajian intensitas nyeri yang dilakukan peneliti kepada 5 orang pasien, didapatkan dua orang pasien mengalami nyeri sedang, yaitu satu orang pasien mengeluh nyeri dengan intensitas nyeri 5, dan satu orang pasien mengeluh nyeri dengan intensitas nyeri 6 , dan tiga orang pasien mengalami nyeri ringan yaitu dua orang pasien mengeluh nyeri dengan intensitas nyeri 2 , dan satu orang pasien mengeluh nyeri dengan intensitas nyeri 3 pasca operasi fraktur ekstremitas bawah.Nyeri pasca bedah fraktur dipengaruhi oleh sejumlah faktor seperti, pengharapan tentang penghilang nyeri, makna nyeri, koping individu, keletihan, pengalaman nyeri masa lalu, usia, dukungan keluarga dan sosial (Hamdani, 2014). Faktor-faktor ini dapat meningkatkan atau menurunkan persepsi dan respon terhadap 
nyeri yang dialami oleh pasien secara individual. Karena keterbatasan karakteristik, beberapa faktor yang diteliti oleh peneliti adalah usia, jenis kelamin, tingkat pendidikan, pengalaman nyeri sebelumnya, mekanisme koping dan dukungan keluarga.

Berdasarkan latar belakang di atas peneliti tertarik untuk melakukan penelitian lebih lanjut tentang "Faktorfaktor yang Mempengaruhi Intensitas Nyeri Pasien Pasca Operasi Fraktur Ekstremitas Bawah di BRSU Tabanan".

\section{Tujuan}

Adapun tujuan dari penelitian ini yaitu bertujuan untuk mengetahui faktor-faktor yang mempengaruhi intensitas nyeri pasien pasca operasi fraktur ekstremitas bawah di Ruang Bougenvile BRSU Tabanan.

\section{Metode}

Penelitian ini merupakan penelitian kuantitatif dengan rancangan penelitian deskriptif analitik melalui pendekatan cross sectional. Populasi dalam penelitian ini adalah semua pasien pasca operasi fraktur ekstremitas bawah yang dirawat di BRSU Tabanan Bali. Pengambilan sampel dalam penelitian ini menggunakan teknik Insidental Sampling yaitu metode pengambilan sampel dengan memilih siapa yang kebetulan ada/dijumpai dan jumlah sampel dalam penelitian ini yaitu 30 responden. Penelitian ini dilakukan di ruang Bougenvile BRSU Tabanan Bali. Penelitian dimulai pada tanggal 1 Januari sampai 30 Maret 2018. Alat pengumpulan data pada penelitian ini melalui kuesioner. Analisa data dalam penelitian ini menggunakan Uji Korelasi untuk variabel usia, Uji T-independen untuk variabel jenis kelamin, pengalaman operasi yang menyebabkan nyeri, mekanisme koping, dukungan keluarga, dan Uji Anova untuk variabel tingkat pendidikan.
Hasil

Hasil Uji Univariat

Usia

Tabel 1 Distribusi Responden menurut Usia

\begin{tabular}{cccccc}
$\begin{array}{c}\text { Varia- } \\
\text { bel }\end{array}$ & Mean & SD & Min & Max & $\begin{array}{c}95 \% \\
\text { CI }\end{array}$ \\
\hline $\begin{array}{c}\text { Usia } \\
\text { (tahun) }\end{array}$ & 43,87 & $\begin{array}{c}14,4 \\
43\end{array}$ & 20 & 72 & $\begin{array}{c}38,47- \\
49,26\end{array}$ \\
\hline
\end{tabular}

Berdasarkan tabel 1 didapatkan rata-rata usia responden yang mengalami nyeri pasca operasi fraktur ekstremitas bawah adalah 43,87 tahun (95\% CI : 38,47 - 49,26), dengan standar deviasi 14,443 tahun, usia termuda 20 tahun dan tertua 72 tahun. Diyakini $95 \%$ responden adalah diantara 38 tahun sampai dengan 49 tahun.

\section{Jenis Kelamin}

Tabel 2 Distribusi Responden menurut Jenis Kelamin

\begin{tabular}{ccc}
\hline Jenis Kelamin & $\mathrm{f}$ & $\%$ \\
\hline Laki-laki & 20 & 66,7 \\
Perempuan & 10 & 33,3 \\
\hline Total & 30 & 100 \\
\hline
\end{tabular}

Berdasarkan tabel2 menunjukkan bahwa jenis kelamin responden yang mengalami nyeri pasca operasi fraktur ekstremitas bawah yaitu laki-laki berjumlah 20 responden $(66,7 \%)$ dan perempuan berjumlah 10 responden $(33,3 \%)$.

\section{Tingkat Pendidikan}

Tabel 3 Distribusi Responden menurut Tingkat Pendidikan

\begin{tabular}{ccc}
\hline Pendidikan & $\mathrm{f}$ & $\%$ \\
\hline Tingkat Dasar & 5 & 16,7 \\
Tingkat Menengah & 13 & 43,3 \\
Perguruan Tinggi & 12 & 40,0 \\
\hline Total & 30 & 100 \\
\hline
\end{tabular}

Berdasarkan tabel3 menunjukkan bahwa tingkat pendidikan responden dengan pendidikan dasar yang mengalami nyeri pasca operasi fraktur ekstremitas bawah adalah sebanyak 5 responden $(16,7 \%)$, responden dengan pendidikan menengah sebanyak 13 responden $(43,3 \%)$ dan responden dengan pendidikan tinggi sebanyak 12 responden $(40,0 \%)$. 


\section{Pengalaman Operasi yang Menyebabkan Nyeri}

Tabel 4 Distribusi Responden menurut Pengalaman Operasi

\begin{tabular}{ccc}
\hline Pengalaman Operasi & $\mathrm{f}$ & $\%$ \\
\hline Pernah & 7 & 23,3 \\
Tidak pernah & 23 & 76,7 \\
\hline Total & 298 & 100 \\
\hline
\end{tabular}

Berdasarkan tabel4 menunjukkan bahwa pengalaman nyeri responden sebelumnya selama 3 bulan terakhir menunjukkan bahwa responden yang pernah mengalami nyeri karena tindakan pembedahan atau operasi sebelumnya berjumlah 7 responden $(23,3 \%)$, sedangkan yang tidak pernah mengalami nyeri karena tindakan pembedahan atau operasi sebelumnya berjumlah 23 responden (76,7\%).

\section{Mekanisme Koping}

Tabel 5 Distribusi Responden menurut Mekanisme Koping

\begin{tabular}{ccc}
\hline Mekanisme Koping & $\mathrm{f}$ & $\%$ \\
\hline Adaptif & 13 & 43,3 \\
Maladaptif & 17 & 56,7 \\
\hline Total & 30 & 100 \\
\hline
\end{tabular}

Berdasarkan tabel5 menunjukkan bahwa mekanisme koping responden dengan mekanisme koping adaptif berjumlah 13 responden $(43,3 \%)$, dan mekanisme koping maladaptif berjumlah 17 responden $(56,7 \%)$.

\section{Dukungan Keluarga}

Tabel 6 Distribusi Responden menurut Dukungan Keluarga

\begin{tabular}{ccc}
\hline Dukungan Keluarga & $\mathrm{f}$ & $\%$ \\
\hline Kurang & 16 & 53,3 \\
Baik & 14 & 46,7 \\
\hline Total & 30 & 100 \\
\hline
\end{tabular}

Berdasarkan tabel6 menunjukkan bahwa dukungan keluarga responden dengan dukungan keluarga kurang berjumlah 16 responden $(53,3 \%)$, dan dukungan keluarga baik berjumlah 14 responden $(46,7 \%)$.

\section{Intensitas Nyeri}

Tabel 7 Distribusi Responden menurut Intensitas Nyeri

\begin{tabular}{cccccc}
\hline $\begin{array}{c}\text { Varia- } \\
\text { bel }\end{array}$ & Mean & SD & $\begin{array}{c}\text { M } \\
\text { in }\end{array}$ & Max & $\begin{array}{c}95 \% \\
\text { CI }\end{array}$ \\
\hline $\begin{array}{c}\text { Intensitas } \\
\text { Nyeri }\end{array}$ & 4,00 & 1,44 & 2 & 8 & $\begin{array}{c}3,46 \\
- \\
4,54\end{array}$ \\
\hline
\end{tabular}

Berdasarkan tabel 7 menunjukkan rata-rata intensitas nyeri pasien pasca operasi fraktur ekstremitas bawah adalah 4 dengan standar deviasi 1,438 (95\% CI : 3,46 - 4,54), intensitas nyeri terendah adalah 2 dan tertinggi adalah 8. Diyakini 95\% intensitas nyeri pasien pasca operasi fraktur ekstremitas bawah diantara 3,46 sampai dengan 4,54 .

\section{Hasil Analisa Uji Bivariat \\ Hubungan Usia Responden dengan Intensitas Nyeri Pasien Pasca Operasi Fraktur Ekstremitas Bawah Menggunakan Uji Korelasi \\ Tabel 8 Hubungan Usia Responden Responden dengan Intensitas Nyeri Pasien Pasca Operasi Fraktur Ekstremitas bawah di BRSU Tabanan Bali $(\mathrm{N}=30)$

\begin{tabular}{lccc}
\hline & \multicolumn{3}{c}{$\begin{array}{c}\text { Intensitas Nyeri Pasien Pasca } \\
\text { Operasi }\end{array}$} \\
\cline { 2 - 4 } Variabel & \multicolumn{3}{c}{$\mathbf{P}$} \\
& $\mathbf{r}$ & $\mathbf{R}^{\mathbf{2}}$ & value \\
\hline usia & $-0,184$ & 0,33 & 0,330 \\
\hline
\end{tabular}

Berdasarkan tabel 8 di atas hubungan usia responden dengan intensitas nyeri pasien pasca operasi fraktur ekstremitas bawah menunjukkan hubungan yang lemah $(r=-$ $0,184)$ dan berpola negatif yang artinya semakin muda usia responden semakin tinggi intensitas nyerinya. Nilai koefisien dengan determinasi 0,033 yang artinya intensitas nyeri pasien pasca operasi fraktur ekstremitas bawah dipengaruhi oleh usia responden sebesar $3,3 \%$ dan sisanya dipengaruhi oleh faktor yang lain. Hasil uji statistik didapatkan $\mathrm{p}$ value $=0,330$ yang berarti tidak ada hubungan signifikan antara usia dengan intensitas nyeri pasien pasca operasi fraktur ekstremitas bawah ( $\mathrm{p}$ value $>0,05)$. 
Hubungan Jenis Kelamin, Pengalaman Operasi yang Menyebabkan Nyeri, Mekanisme Koping dan Dukungan Keluarga dengan Intensitas Nyeri Pasien Pasca Operasi Fraktur Ekstremitas Bawah Menggunakan Uji T-Independen

Tabel 9 Hubungan Jenis Kelamin, Pengalaman Operasi, Mekanisme Koping dan Dukungan Keluarga dengan Intensitas Nyeri Pasien Pasca Operasi Fraktur Ekstremitas bawah di BRSU

$$
\text { Tabanan Bali }(\mathrm{N}=30)
$$

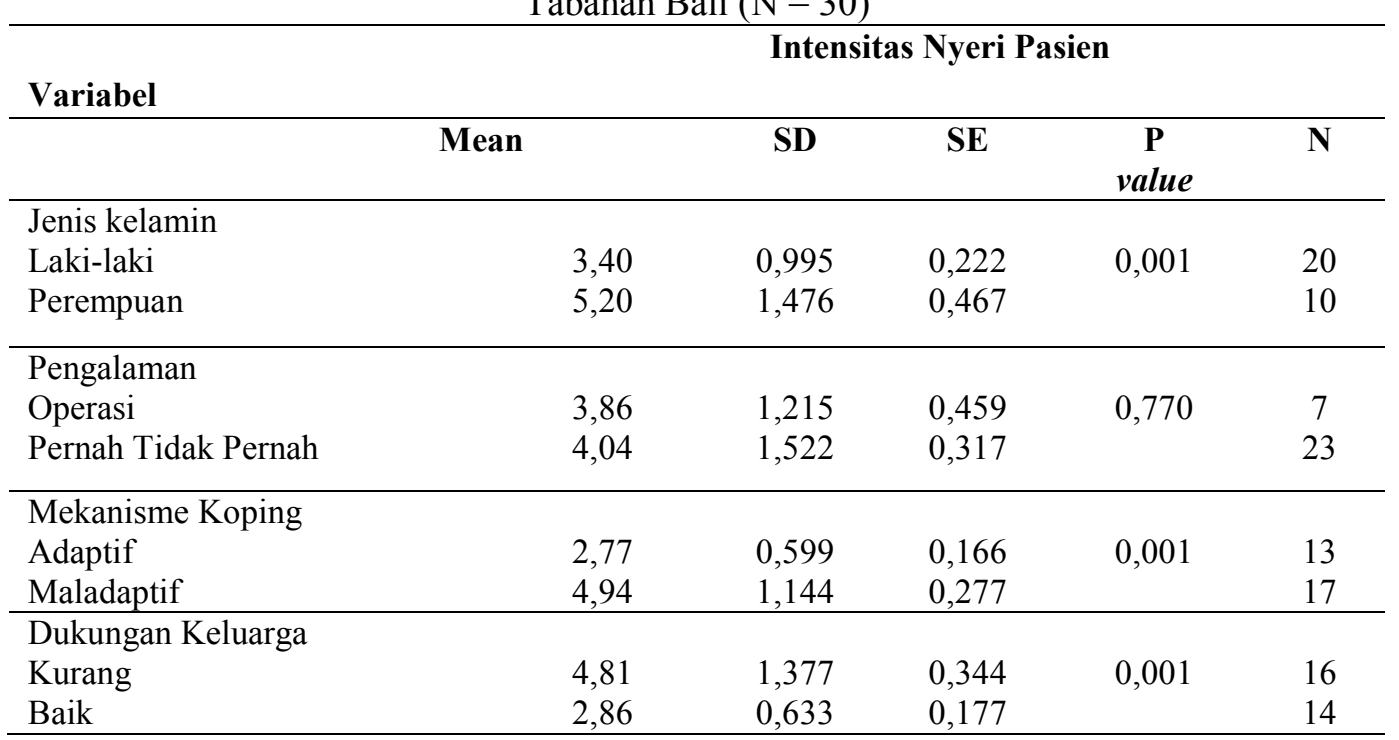

Berdasarkan tabel 5.9 di atas, hasil analisis bivariat didapatkan rata-rata intensitas nyeri pasien pasca operasi fraktur ekstremitas bawah pada responden laki-laki adalah 3,40 dengan standar devisiasi 0,995 , sedangkan pada responden perempuan adalah 5,20 dengan standar deviasi 1,476, hasil uji statistik didapatkan nilai $\mathrm{p}=0,001$, yang berarti ada hubungan yang signifikan antara jenis kelamin dengan intensitas nyeri pasien pasca operasi fraktur ekstremitas bawah ( $\mathrm{p}$ value $>0,05)$.

Berdasarkan pengalaman operasi yang menyebabkan nyeri didapatkan rata-rata intensitas nyeri pasien pasca operasi fraktur ekstremitas bawah pada responden yang pernah mengalami operasi sebelumnya adalah 3, 86 dengan standar deviasi 1,215, sedangkan pada responden yang tidak pernah mengalami operasi sebelumnya adalah 4,04 dengan standar deviasi 1,522. Hasil uji statistik didapatkan nilai $p=0,770$, yang berarti tidak ada hubungan yang signifikan antara pengalaman nyeri sebelumnya dengan intensitas nyeri pasien pasca operasi fraktur ekstremitas bawah ( $p$ value $<0,05)$.

Berdasarkan mekanisme koping didapatkan rata-rata intensitas nyeri pasien pasca operasi fraktur ekstremitas bawah pada responden yang memiliki mekanisme koping adaptif adalah 2,77 dengan standar deviasi 0,599 , sedangkan pada responden yang memiliki mekanisme koping maladaptif adalah 4,94 dengan standar deviasi 1,144. Hasil uji statistik didapatkan nilai $\mathrm{p}=0,001$, yang berarti ada hubungan yang signifikan antara mekanisme koping dengan intensitas nyeri pasien pasca operasi fraktur ekstremitas bawah ( $\mathrm{p}$ value $>0,05$ ).

Berdasarkan dukungan keluarga didapatkan rata-rata intensitas nyeri pasien pasca operasi fraktur ekstremitas bawah pada responden yang memiliki dukungan keluarga kurang adalah 4,81 dengan standar deviasi 1,377, sedangkan pada responden yang memiliki dukungan keluarga baik adalah 2,86 dengan standar deviasi 0,663. Hasil uji statistik didapatkan nilai $\mathrm{p}=0,001$, yang berarti ada hubungan yang signifikan antara mekanisme koping dengan intensitas nyeri pasien pasca operasi fraktur ekstremitas bawah ( $\mathrm{p}$ value $>0,05)$.

\section{Pembahasan}

Hubungan Faktor Usia dengan Intensitas Nyeri Pasien Pasca Operasi Fraktur Ekstremitas Bawah 
Hasil penelitian yang telah dilakukan di BRSU Tabanan, pada bulan Januari - Maret 2018 terhadap 30 responden, hubungan usia responden dengan intensitas nyeri pasien pasca operasi fraktur ekstremitas bawah menunjukkan hubungan berpola negatif $(\mathrm{r}=$ - 0,184) yang artinya semakin muda usia responden semakin tinggi intensitas nyerinya. Hasil uji statistik didapatkan $\mathrm{p}$ value $=0,330$ yang berarti tidak ada hubungan signifikan antara usia dengan intensitas nyeri pasien pasca operasi fraktur ekstremitas bawah ( $\mathrm{p}$ value $>0,05$ ).

Menurut Raoul dan Jean (2015), dimana usia menunjukkan ukuran waktu pertumbuhan dan perkembangan seorang individu. Usia berkolerasi dengan pengalaman, pengalaman berkolerasi dengan pengetahuan, pemahaman dan pandangan terhadap suatu penyakit atau kejadian sehingga akan membentuk persepsi dan sikap. Ditemukan sebagian besar kelompok usia yang lebih muda cenderung mengalami respon nyeri yang berat dibandingkan kelompok usia dewasa (Lukman, 2011).

Hasil penelitian yang dikemukakan oleh Septiani (2015) bahwa tidak ada hubungan yang signifikan antara usia muda (20-40 tahun) dengan usia madya (41-60 tahun) terhadap tingkat nyeri fraktur. Sebagian besar responden yang mempunyai faktor usia dengan kategori usia madya mayoritas memiliki nyeri fraktur yang mengganggu aktifitas yaitu sebanyak 18 orang $(60 \%)$. Dengan nilai signifikasi $0,932 \quad(p>0,05)$, maka hipotesis Ho tidak diterima yang artinya tidak ada hubungan faktor usia dengan nyeri.

Usia mempunyai peranan yang penting dalam mempersepsikan dan mengekspresikan rasa nyeri. Pasien dewasa muda memiliki respon yang berbeda terhadap nyeri dibandingkan pada lansia.Menurut Prawani (2008), orang tua membutuhkan intensitas lebih tinggi dari rangsangan nyeri dibandingkan orang usia muda.Pada pasien dewasa tua menganggap bahwa nyeri merupakan komponen alamiah yang harus mereka terima dari respon penuaan, sehingga keluhan sering diabaikan. Biasanya kondisi nyeri hebat pada dewasa muda dapat dirasakan sebagai keluhan ringan pada dewasa tua. Penjelasan di atas memberikan gambaran pada penelitian ini bahwa dapat disimpulkan intensitas nyeri terkait dengan usia didominasi atau lebih banyak disebabkan oleh kesalahan persepsi, emosi yang labil, prasangka, dan sikap defensif, sehingga individu menutupi sensasi nyeri yang sebenarnya dirasakan.

\section{Hubungan Faktor Jenis kelamin dengan Intensitas Nyeri Pasca Operasi Fraktur Ekstremitas Bawah}

Hasil penelitian yang telah dilakukan di BRSU Tabanan, pada bulan Januari - Maret 2018 terhadap 30 responden, hubungan jenis kelamin responden menunjukkan bahwa intensitas nyeri pasien pasca operasi fraktur ekstremitas bawah pada laki-laki lebih rendah $(3,40)$ dari pada perempuan $(5,20)$. Analisis lebih lanjut menunjukkan bahwa nilai $\mathrm{p}=0,001$, yang berarti ada hubungan yang signifikan antara jenis kelamin dengan intensitas nyeri pasien pasca operasi fraktur ekstremitas bawah ( $\mathrm{p}$ value $<0,05$ ).

Menurut Anggriani (2015), perbedaan jenis kelamin yang menunjukkan bahwa wanita lebih nyeri dari laki-laki ini dapat dipengaruhi oleh beberapa hal yaitu laki-laki memiliki sensitifitas yang lebih rendah dibandingkan wanita atau kurang merasakan nyeri dan wanita kurang toleransi terhadap stimulus nyeri dari pada laki-laki. Saat mengalami nyeri pengobatan ditemukan lebih sedikit pada perempuan, perempuan lebih suka mengkomunikasikan rasa sakitnya, sedangkan laki-laki menerima analgesik opioid lebih sering sebagai pengobatan untuk nyeri (Lukman, 2011).

Hasil penelitian ini sejalan dengan penjelasan yang dikemukakan oleh Wijaya (2014) yang bertujuan untuk meneliti faktorfaktor yang mempengaruhi intensitas nyeri pasien pasca bedah abdomen dalam Konteks Asuhan Keperawatan. Jumlah responden sebesar 71 pasien (21 laki-laki dan 50 wanita). Intensitas nyeri menggunakan Visual Analog Scale (VAS) dan Numeric Rating Scale (NRS). Hasil penelitian menunjukkan bahwa pasien wanita mempunyai intensitas nyeri lebih tinggi dari pada laki-laki dimana data diperoleh setelah 30 menit pemberian analgesik.

Karakteristik jenis kelamin memegang peranan tersendiri dalam merespon nyeri, 
dalam pengkajian keperawatan dapat dijadikan sebagai pedoman dalam merumuskan asuhan keperawatan sehingga dalam melaksanakan asuhan keperawatan pada pasien laki-laki dapat menggunakan cara pendekatan yang berbeda dibandingkan dengan pasien perempuan khususnya untuk pengelolaan nyeri.

\section{Hubungan Faktor Tingkat Pendidikan dengan Intensitas Nyeri Pasca Operasi Fraktur Ekstremitas Bawah}

Hasil penelitian yang telah dilakukan di BRSU Tabanan, pada bulan Januari - Maret 2018 terhadap 30 responden, hubungan tingkat pendidikan responden menunjukkan bahwa intensitas nyeri pasien pasca operasi fraktur ekstremitas bawah dengan pendidikan menengah lebih tinggi $(5,08)$, dibandingkan dengan pendidikan dasar $(4,00)$ dan pendidikan tinggi $(2,83)$. Analisis lebih lanjut menunjukkan bahwa nilai $\mathrm{p}=$ 0,001 , yang berarti ada hubungan yang signifikan antara jenis tingkat pendidikan dengan intensitas nyeri pasien pasca operasi fraktur ekstremitas bawah ( $\mathrm{p}$ value $<0,05$ ).

Dalam kamus besar bahasa Indonesia pendidikan merupakan proses perubahan sikap dan tingkah laku seseorang dalam usaha mendewasakan diri manusia melalui upaya pengajaran dan latihan. Hal tersebut berhubungan dengan strategi koping yaitu konsekuensi masing-masing individu untuk menilai suatu keadaan. Menurut Notoadmodjo (2010), tingkat pendidikan adalah salah satu faktor yang menentukan terhadap terjadinya perubahan perilaku, dimana semakin tinggi tingkat pendidikan seseorang ini menyebabkan semakin banyak bahan, materi dan pengetahuan yang dimiliki untuk mencapai perubahan tingkah laku yang baik.Menurut lukman (2011), responden yang berpendidikan tinggi lebih mampu menggunakan pemahaman mereka dalam merespon kejadian secara adaptif dibandingkan kelopok responden yang berpendidikan redah.

Berbeda halnya dengan penelitian yang dilakukan oleh Wijaya (2014) yang terkait dengan hubungan tingkat pendidikan terhadap intensitas nyeri pasca bedah abdomen menunjukkan bahwa tidak ada hubungan signifikan antara tingkat nyeri dengan tingkat pendidikan. Hasil penelitian menunjukkan bahwa intensitas nyeri pasien pasca bedah abdomen pada tingkat pendidikan tinggi lebih tinggi dari pada tingkat pendidikan rendah dan menengah. Analisis lebih lanjut didapatkan nilai $\mathrm{p}=$ 0,409 , berarti tidak ada hubungan yang signifikan antara tingkat pendidikan dengan intensitas nyeri pasien pasca bedah abdomen ( $\mathrm{p}$ value $>0,05$ ).

Tingkat pendidikan mempunyai hubungan negatif dengan persepsi nyeri, semakin rendah pendidikan menyebabkan peningkatan intensitas nyeri dan disabilitas akibat nyeri. Di dalam pengkajian keperawatan tingkat pendidikan diperlukan karena erat kaitannya terhadap tingkat pengetahuan pasien tentang pengelolaan nyeri. Tingkat pendidikan sering dihubungkan dengan pengetahuan, oleh sebab itu seseorang berpendidikan tinggi diasumsikan lebih mudah untuk menyerap informasi, sehingga dalam pemberian asuhan keperawatan dapat disesuaikan dengan tingkat pendidikan. Tingkat pendidikan adalah salah satu faktor yang menentukan tingkat kemampuan pemahaman pasien dalam mengatasi nyeri yang dialami.

\section{Hubungan Faktor Pengalaman Operasi Yang Menyebabkan Nyeri dengan Intensitas Nyeri Pasca Operasi Fraktur Ekstremitas Bawah}

Hasil penelitian yang telah dilakukan di BRSU Tabanan, pada bulan Januari - Maret 2018 terhadap 30 responden, hubungan pengalaman operasi yang menyebabkan nyeri menunjukkan bahwa intensitas nyeri pasien pasca operasi fraktur ekstremitas bawah yang pernah mengalami tindakan operasi yang menyebabkan nyeri memiliki intensitas nyeri lebih rendah $(3,83)$ dibandingkan $(4,04)$. Hasil uji statistik didapatkan nilai $\mathrm{p}=0$, 770, yang berarti tidak ada hubungan yang signifikan antara pengalaman nyeri sebelumnya dengan intensitas nyeri pasien pasca operasi fraktur ekstremitas bawah ( $\mathrm{p}$ value $<0,05$ ). 
Pengalaman operasi yang menyebabkan nyeri tidak selalu berarti bahwa individu tersebut akan menerima nyeri dengan lebih mudah pada masa yang akan datang. Apabila individu mengalami nyeri, dengan jenis yang berulang-ulang, tetapi kemudian nyeri tersebut dengan berhasil dihilangkan, akan lebih mudah individu tersebut menginterpretasikan sensasi nyeri. Akibatnya pasien akan lebih siap dalam melakukan tindakan-tindakan untuk menghilangkan nyeri tersebut (Andarmoyo, 2013). Hal ini sesuai dengan teori yang menyatakan responden yang pernah mengalami tindakan operasi sebelumnya memiliki intensitas nyeri yang lebih rendah dibandingkan dengan yang tidak pernah mengalami tindakan operasi sebelumnya ini disebabkan karena nyeri yang dialami pasca tindakan operasi sebelumnya dapat berhasil untuk dihilangkan, maka akan lebih mudah untuk individu tersebut melakukan tindakantindakan yang diperlukan dalam menghilangkan nyeri yang dirasakan (Dewi, 2017)

Hasil penelitian ini sejalan dengan penjelasan yang dikemukakan oleh Wijaya (2014) dimana hasil penelitian menunjukkan bahwa intensitas nyeri pasien pasca bedah abdomen pada pengalaman nyeri sebelumnya, tidak pernah mengalami nyeri sebelumnya lebih tinggi dari pada responden yang pernah mengalami nyeri sebelumnya. Analisis lebih lanjut didapatkan nilai $\mathrm{p}=$ 0,634 , berarti tidak ada hubungan yang signifikan antara pengalaman nyeri sebelumnya dengan intensitas nyeri pasca bedah abdomen ( $\mathrm{p}$ value $>0,05)$.

Pengalaman masa lalu terhadap penyakit baik yang positif maupun negatif dapat mempengaruhi perkembangan keterampilan dalam menggunakan koping. Pengalaman operasi yang menyebabkan nyeri mempunyai implikasi terhadap pengkajian keperawatan. Jika pasien tidak pernah merasakan nyeri, maka persepsi negatif pertama nyeri yang timbul dapat mengganggu koping terhadap nyeri. Apabila pasien tidak menyadari hal ini pasien akan memandang awitan nyeri sebagai komplikasi yang serius dan menjadi stressor di dalam dirinya. Sedangkan pasien yang pernah mengalami nyeri sebelumnya maka persepsi pasca operasi fraktur adalah hal umum bagi pasien untuk mengalami nyeri insisi selama beberapa hari. Sehingga ini akan membantu pasien untuk lebih siap dalam melakukan tindakan-tindakan untuk menghilangkan nyeri.

\section{Hubungan Faktor Mekanisme Koping dengan Intensitas Nyeri Pasca Operasi Fraktur Ekstremitas Bawah}

Hasil penelitian yang telah dilakukan di BRSU Tabanan, pada bulan Januari - Maret 2018 terhadap 30 responden, hubungan mekanisme koping menunjukkan bahwa intensitas nyeri pasien pasca operasi fraktur ekstremitas bawah dengan mekanisme koping adaftif memiliki intensitas nyeri lebih rendah $(2,77)$ dibandingkan dengan responden dengan mekanisme koping maladaftif (4,94). Hasil uji statistik didapatkan nilai $\mathrm{p}=0,001$, yang berarti ada hubungan yang signifikan antara mekanisme koping dengan intensitas nyeri pasien pasca operasi fraktur ekstremitas bawah ( $\mathrm{p}$ value $>$ $0,05)$.

Mekanisme koping adalah cara yang dilakukan untuk merubah lingkungan, situasi atau menyelesaikan masalah yang sedang dirasakan atau dihadapinya (Dewi, 2017). Berhasil atau tidaknya strategi koping yang digunakan pasien dapat mempengaruhi intensitas nyeri yang dirasakannya. Setiap individu dalam menghadapi masalah akan selalu bereaksi positif atau negatif, perbedaan ini akan mempengaruhi dalam penilaian mekanisme koping yang digunakan seorang pasien dalam menghadapi masalah nyeri yang dialaminya (Kemp, 2010)

Hasil penelitian ini sejalan dengan penjelasan yang dikemukakan oleh Nurhafizah (2012) yang bertujuan untuk meneliti hubungan strategi koping dengan intensitas nyeri pasien post operasi, terhadap 54 responden. Analisa data yang digunakan adalah Chi-Square Test. Hasil penelitian menujukkanterdapat hubungan yang signifikan antara strategi koping dengan intensitas nyeri pasien pasca bedah abdomen dengan nilai signifikansi $(\mathrm{p})=0,018$ $(<0,05)$.

Koping yang adaptif akan menghasilkan adaptasi yang menetap yang merupakan 
kebiasaan baru dan perbaikan dari situasi lama, sedangkan koping yang tidak efektif berakhir dengan maladaptif yaitu perilaku yang menyimpang dari keinginan normatif dan dapat merugikan diri sendiri maupun orang lain atau lingkungannya.

Umumnya pasien belum mengetahui cara yang bisa dilakukan untuk mengurangi nyeri selain dengan obat-obatan, dalam hal ini erat kaintannya dengan penggunaan mekanisme koping pasien. Sehingga ini menyebabkan pasien sering bereaksi terhadap nyeri secara salah atau dengan kata lain pasien umumnya menggunakan mekanisme koping yang maladaptif dalam usaha untuk mencegah serangan nyeri yang dirasakannya, hal tersebut akan menambah nyeri karena rasa nyeri menjadi pusat perhatiannya padahal sebenarnya pasien dapat berpartisipasi aktif dalam latihan pernafasan untuk mengurangi nyeri pasca operasi.

Di dalam asuhan keperawatan perawat sangat perlu mengetahui bagaimana pasien dalam merespon nyeri baik dengan mekanisme koping adaptif atau maladaptif sehingga ini akan mempermudah dalam menentukan cara pendekatan atau penjelasan yang bisa diberikan untuk mengurangi atau menghilangkan rasa nyeri yang dirasakan pasien pasca operasi.

\section{Hubungan Faktor Dukungan Keluarga dengan Intensitas Nyeri Pasca Operasi Fraktur Ekstremitas Bawah}

Hasil penelitian yang telah dilakukan di BRSU Tabanan, pada bulan Januari - Maret 2018 terhadap 30 responden, hubungan dukungan keluarga menunjukkan bahwa intensitas nyeri pasien pasca operasi fraktur ekstremitas bawah dengan dukungan keluarga baik memiliki intensitas nyeri lebih rendah $(2,86)$ dari pada responden dengan dukungan keluarga kurang $(4,81)$. Hasil uji statistik didapatkan nilai $\mathrm{p}=0,001$, yang berarti ada hubungan yang signifikan antara mekanisme koping dengan intensitas nyeri pasien pasca operasi fraktur ekstremitas bawah ( $\mathrm{p}$ value $>0,05)$

Dukungan keluarga adalah sikap, tindakan dan penerimaan keluarga terhadap anggotanya(McWilliams, Higgins, Dick, \& Verrier, 2014). Anggota keluarga memandang bahwa orang yang bersifat mendukung selalu siap memberikan pertolongan dan bantuan jika diperlukan. Jenis dukungan yang diberikan keluarga untuk mengurangi nyeri pasien itu sendiri adalah dukungan informasional, dimana keluarga memberikan nasehat, saran, dukungan jasmani maupun rohani (Setiadi, 2008).

Hasil penelitian ini sejalan dengan penjelasan yang dikemukakan oleh Saraswati (2015), hubungan pendampingan suami dengan intensitas nyeri persalinan kala I, terhadap 31 responden. Menunjukkan hasil uji statistik Kendall Tau diketahui bahwa nilai $\mathrm{t}$ hitung sebesar 0,522 dengan signifikansi $\mathrm{p}=0,000(p<0,05)$ maka $\mathrm{Ha}$ diterima sehingga dapat disimpulkan bahwa terdapat hubungan yang bermakna secara statistik antara pendampingan suami dengan intensitas nyeri persalinan kala I di RS PKU Muhammadiyah Yogyakarta. Nilai t hitung sebesar 0,522 menunjukkan keeratan hubungan sedang dan koefisien korelasi berpola negatif artinya semakin rendah pendampingan suami maka intensitas nyeri persalinan kala I semakin berat.

Dukungan dari orang yang terdekat merupakan bentuk dukungan sosial yang dapat digunakan sebagai motivasi untuk meningkatkan aktivitas fisik. Individu yang mengalami nyeri sering kali bergantung kepada anggota keluarga atau teman dekat untuk mendapatkan dukungan dan perlindungan. Individu yang sedang mengalami nyeri lebih sering bergantung kepada keluarga untuk membantu dalam aktifitas, memperoleh dukungan dan bisa melindunginya. Tidak adanya dukungan dari keluarga atau teman dekat lebih memungkinkan untuk nyeri yang dirasakan individu tersebut menjadi bertambah. Dukungan keluarga dapat menimbulkan efek penyangga yaitu dukungan keluarga menahan efek-efek negatif dari stres terhadap kesehatan.

\section{Kesimpulan}

Berdasarkan hasil uji univariat didapatkan gambaran karakteristik dari 30 responden menunjukkan angka usia yang mengalami nyeri pasca operasi fraktur ekstremitas bawah adalah rata- 
rata berusia 44 tahun Jenis kelamin responden yang mengalami nyeri pasca operasi fraktur ekstremitas bawah didominasi berjenis kelamin laki-laki sebanyak 20 responden $\quad(66,7 \%)$ sedangkan perempuan sebanyak 10 responden 33,3\%. Responden berpendidikan dasar sebanyak 5 responden $\quad(16,7 \%)$, berpendidikan menengah sebanyak 13 responden $(43,3 \%)$ dan berpendidikan tinggi sebanyak 12 responden (40,0\%). Responden yang sudah pernah memiliki pengalaman operasi yang menyebabkan nyeri sebanyak 7 responden $(23,3 \%)$ dan yang tidak pernah sebanyak 23 responden $(76,7 \%)$. Responden dengan mekanisme koping adaptif sebanyak 13 responden $(43,3 \%)$, dan mekanisme koping maladaptif sebanyak 17 responden $(56,7 \%)$. Responden dengan dukungan keluarga kategori dukungan kurang sebanyak 16 responden $(53,3 \%)$ dan dukungan baik sebanyak 14 responden $(46,7 \%)$.

Berdasarkan hasil uji statistik faktorfaktor yang berhubungan secara signifikan dengan intensitas nyeri pasien pasca operasi fraktur ekstremitas bawah adalah jenis kelamin $(\mathrm{p}=0,001)$, tingkat pendidikan $(\mathrm{p}=0,001)$, mekanisme koping $(\mathrm{p}=0,001)$, dukungan keluarga $(\mathrm{p}=0,001)$. Sedangkan faktor-faktor yang tidak berhubungan dengan intensitas nyeri pasien pasca operasi fraktur ekstremitas bawah adalah usia ( $p$ $=0,330)$, pengalaman operasi yang menyebabkan nyeri $(\mathrm{p}=0,770)$.

\section{Daftar Pustaka}

Apley, G., \& Solomon, L. (2013). Buku Ajar Orthopedi dan Fraktur SistemApley. Jakarta : Widya Medika.

Andarmoyo, S. (2013). Konsep dan Proses Keperawatan Nyeri. Yogyakarta : ArRuzz Media.

Dickson, W. L. (2006). Increasing Coping resource: an experimental intervention approach. Journal medical association. Diakses pada tanggal 16 Juli 2017 dari http://scholarworks.gsu.edu/cgi/viewc ontent.cgi? article $=1005 \&$ context $=\mathrm{cps}$

Dewi, A. P. (2017). Faktor-faktor Yang Mempengaruhi Tingkat Kecemasan Pada Pasien Pra Operasi Sectio Caesarea. Skripsi Program Studi S1 Keperawatan STIKES Bina Usada Bali.

Damayanti, W. P. (2014). Faktor-faktor Yang Mempengaruhi Tingkat Kecemasan Pasien Pra Operasi Fraktur di Ruang Bedah RSUD Badung. Skripsi Program Studi S1 Keperawatan STIKES Bina Usada Bali.

Hung, M. (2016). The relationship between family support; pain and depression in elderly with arthritis. Psychiatric Rehabilitation Journal, 35 (5),403-405.

Kemp, C. (2010). Klien Sakit Terminal: Seri Asuhan Keperawatan (Edisi 2). Jakarta: EGC.

Katsarou, A. (2012). Validation of a Greek Version of PSS-14; Global Measure of Perceived Stress. Cen Eur Journal Public Health, 20 (2),104-109

Li, Liu, \& Herr. (2007). Post Operatif Pain Intensity Assessment: A Comparison of Four Scale In Chinese adult. Journal Intensity of Pain. Diperoleh tanggal 12 Mei $2017 . \quad$ Dari http://www.ncbi.nlm.gov/

Lukman, N. (2011). Asuhan Keperawatan Pada Klien Dengan Gangguan Sistem Muskuloskeletal. Jakarta : Selemba.

Mackintosh, C. (2007). Assesment and management Patients with PostOperative pain. Nursing Standard, 22 (5). 49

McLafferty, E., \& Farley, A. (2008). Assesing pain in patients. Nursing Standard, 22 (25), 42

McWilliams, L. A., Higgins, K. S., Dick, B. D., \& Verrier, M. J. (2014). A longitudinal investigation of painrelated social support preferences in a chronic pain treatment sample.The 
Clinical Journal of Pain, 30 (8), 672 678.

Murni, K. T. (2013). Faktor-faktor yang Mempengaruhi Intensitas Nyeri pada Pasien Pasca Bedah Laparatomi. Program Studi Ilmu Keperawatan Medistra Lubuk Pakam

Nurchairiah, A., Hasneliz, Y., Indriati, G. (2013). Efektifitas Kompres Dingin Terhadap Intensitas Nyeri Pada Pasien Fraktur Tertutup di Ruang Dahlia RSUD Arifin Achmad. Diperoleh tanggal 10 Mei 2017.

Dari http://jom.unri.ac.id/index.php/JOM PSIK/article/download/3438/3334.

Nursalam. (2016). Konsep dan Penerapan Metodelogi Penelitian Ilmu Keperawatan. Jakarta : Salemba Medika.

Pasaribu, I. S. (2011). Intensitas Nyeri dan Perilaku Nyeri pada Pasien Pasca Bedah ORIF di RSUP H. Adam Malik Medan. Skripsi. Medan: Fakultas Keperawatan Universitas Sumatera Utara.

Plotino, N. M., Grande, P. F., \& Porciani. (2014). Deformation and fracture incidence of Reciproc instruments: a clinical evaluation. Quintessence International 41, 47988.

Rendy, M. C., \& Margareth. (2012). Asuhan Keperawatan Medikal Bedah dan Penyakit Dalam. Yogyakarta : Nuha Medika.

Raoul, D., \& Jean, P. (2015). Impact of Age on Pain Perception for Typical Painful Diagnoses in the Emergency Department. The Journal of Emergency

Medicine.https://doi.org/10.1016/j.je mermed.2015.06.074

Scheid, T. L., \& Brown, T. N. (2010). A Handbook for Study of Mental Health: Social Contexts, Theories, and Systems 2nd Edition. New York: Cambridge University Press.

Saputra, I. B. A. (2013). Profil Penggunaan Analgetika Pada Pasien Nyeri Akut Pasca Bedah Di
RSUP Sanglah. Diperoleh pada tanggal 20 mei 2017.

Septiani, L. (2015). Analisis FaktorFaktor Yang Mempengaruhi Nyeri Pada Klien Fraktur Di RS PKU Muhammadiyah Yogyakarta. Program Studi Ilmu Keperawatan Sekolah Tinggi Ilmu Kesehatan Aisyiyah Yogyakarta

Tzanetakis, G.N., Kontakiotis, E.G., Maurikou, D., \& Marzelou, M.P. (2008). Prevalence and management of instrument fracture in the postgraduate endodontic program at the Dental School of Athens: a five-year retrospective clinical study. Journal of Endodontics 34, 675-8.

Unit Data Pelayanan BRSU Tabanan Bali, (2015). Informasi Pasien Dengan Fraktur Instalasi Rawat Inap. Tabanan : BRSU Tabanan. Tidak dipublikasikan.

Unit Data Pelayanan BRSU Tabanan Bali, (2016). Informasi Pasien Dengan Fraktur Instalasi Rawat Inap. Tabanan : BRSU Tabanan. Tidak dipublikasikan.

Unit Data Pelayanan BRSU Tabanan Bali, (2017). Informasi Pasien Dengan Fraktur Instalasi Rawat Inap. Tabanan : BRSU Tabanan. Tidak dipublikasikan.

Unit Data Pelayanan BRSU Tabanan Bali, (2018). Informasi Pasien Dengan Fraktur Instalasi Rawat Inap. Tabanan : BRSU Tabanan. Tidak dipublikasikan.

Videback, S. (2008). Buku Ajar Keperawatan Jiwa. Jakarta: EGC

Wijaya, I. P. A. (2014). Analisis Faktorfaktor yang Mempengaruhi Intensitas Nyeri Pasien Pasca Bedah Abdomen Dalam Kontek Asuhan Keperawatan di RSUD Badung Bali. Diperoleh pada tanggal 28 mei 2017. Dari http://www.triatma-

maino.ac.id/ojsstikes/index.php/JDK3/a rticle/download/35/28.

WHO. (2011). Decade of action or road safety: Indonesia. Mei 15 2017, http://who.searo/int. 